University of Nebraska - Lincoln

DigitalCommons@University of Nebraska - Lincoln

Public Health Resources

Public Health Resources

2014

Isolation and molecular characterization of Salmonella enterica serovar Enteritidis from poultry house and clinical samples during 2010

Ezat H. Mezal

U.S. Food and Drug Administration

Ashley Sabol

Centers for Disease Control and Prevention

Mariam A. Khan

University of Central Arkansas

Nawab Ali

University of Arkansas at Little Rock

Rossina Stefanova

The Arkansas Department of Health

See next page for additional authors

Follow this and additional works at: http://digitalcommons.unl.edu/publichealthresources

Mezal, Ezat H.; Sabol, Ashley; Khan, Mariam A.; Ali, Nawab; Stefanova, Rossina; and Khan, Ashraf A., "Isolation and molecular characterization of Salmonella enterica serovar Enteritidis from poultry house and clinical samples during 2010" (2014). Public Health Resources. 297.

http://digitalcommons.unl.edu/publichealthresources/297

This Article is brought to you for free and open access by the Public Health Resources at DigitalCommons@University of Nebraska - Lincoln. It has been accepted for inclusion in Public Health Resources by an authorized administrator of DigitalCommons@University of Nebraska - Lincoln. 
Authors

Ezat H. Mezal, Ashley Sabol, Mariam A. Khan, Nawab Ali, Rossina Stefanova, and Ashraf A. Khan 


\title{
Isolation and molecular characterization of Salmonella enterica serovar Enteritidis from poultry house and clinical samples during 2010
}

\author{
Ezat H. Mezal ${ }^{\mathrm{a}, \mathrm{b}, \mathrm{f}}$, Ashley Sabol ${ }^{\mathrm{c}}$, Mariam A. Khan ${ }^{\mathrm{d}}$, Nawab Ali ${ }^{\mathrm{b}}$, Rossina Stefanova ${ }^{\mathrm{e}}$, \\ Ashraf A. Khan ${ }^{a, *}$ \\ ${ }^{a}$ Microbiology Division, National Center for Toxicological Research, U.S. Food and Drug Administration, Jefferson, AR 72079, USA \\ ${ }^{\mathrm{b}}$ University of Arkansas at Little Rock, Little Rock, AR 72205, USA \\ ${ }^{c}$ Centers for Disease Control and Prevention, Atlanta, GA 30333, USA \\ ${ }^{\mathrm{d}}$ University of Central Arkansas, Conway, AR, USA \\ e The Arkansas Department of Health, Little Rock, AR, USA \\ ${ }^{\mathrm{f}}$ University of Thi-Qar, Science of College, Biology of Dept., Thi-Qar, Iraq
}

\section{A R T I C L E I N F O}

\section{Article history:}

Received 18 May 2012

Received in revised form 12 July 2013

Accepted 9 August 2013

Available online 27 August 2013

\section{Keywords:}

Salmonella Enteritidis

MLVA

Pulsed-field gel electrophoresis

Plasmid

\begin{abstract}
A B S T R A C T
A total of 60 Salmonella enterica serovar (ser.) Enteritidis isolates, 28 from poultry houses and 32 from clinical samples, were isolated during 2010. These isolates were subjected to testing and analyzed for antibiotic resistance, virulence genes, plasmids and plasmid replicon types. To assess genetic diversity, pulsed-field gel electrophoresis (PFGE) fingerprinting, using the XbaI restriction enzyme, Multiple-Locus Variable-Number Tandem Repeat Analysis (MLVA) and plasmid profiles were performed. All isolates from poultry, and 10 out of 32 clinical isolates were sensitive to ampicillin, chloramphenicol, gentamicin, kanamycin, nalidixic acid, sulfisoxazole, streptomycin, and tetracycline. Twenty-one of thirty-two clinical isolates were resistant to ampicillin and tetracycline, and one isolate was resistant to nalidixic acid. PFGE typing of sixty ser. Enteritidis isolates by XbaI resulted in 10-12 bands and grouped into six clusters each with similarity from $95 \%$ to $81 \%$. The MLVA analysis of sixty isolates gave 18 allele profiles with the majority of isolates displayed in three groups, and two clinical isolates found to be new in the PulseNet national MLVA database. All isolates were positive for 12 or more of the 17 virulence genes mostly found in S. enterica (spvB, spiA, pagC, $m \operatorname{sg} A$, invA, sipB, $\operatorname{prg} H, \operatorname{spaN}, \operatorname{org} A$, tolC, iroN, sitC, IpfC, sifA, sopB, and pefA) and negative for one gene $(c d t B)$. All isolates carried a typical $58 \mathrm{~kb}$ plasmid, type $I n c / F I I A$. Three poultry isolates and one clinical isolate carried small plasmids with 3.8, 6, 7.6 and $11.5 \mathrm{~kb}$. Ten of the clinical isolates carried plasmids, with sizes 36 and $38 \mathrm{~kb}$, types $I n c L / M$ and $I n c N$, and one isolate carried an $81 \mathrm{~kb}$ plasmid, type IncI. Southern hybridization of a plasmid with an Inc/FIIA gene probe hybridized one large $58 \mathrm{~kb}$ plasmid in all isolates. Several large and small plasmids from poultry isolates were not typed by our PCR-based method. These results confirmed that PFGE fingerprinting has limited discriminatory power for ser. Enteritidis in both poultry and clinical sources. However, the plasmid and MLVA allele profiles were a useful and important epidemiology tool to discriminate outbreak strains of ser. Enteritidis from poultry and clinical samples.
\end{abstract}

Published by Elsevier Ltd.

\section{Introduction}

Salmonella is one of the leading causes of foodborne illnesses worldwide. The Centers for Disease Control and Prevention (CDC) has estimated that 9.4 million foodborne illnesses, 55,961 hospitalizations and 1351 deaths occur in the United State each year

\footnotetext{
* Corresponding author. Tel.: +1 870543 7601; fax: +1 8705437307.

E-mail addresses: ashraf.khan@hotmail.com, Ashraf.khan@fda.hhs.gov (A.A. Khan).
}

(Scallan et al., 2011). Non-typhoidal Salmonella causes an estimated 1 million illnesses with approximately 20,000 hospitalizations and approximately 378 deaths each year (Scallan et al., 2011). Furthermore Salmonella infections are usually associated with the consumption of contaminated food products from poultry, pigs and ruminants, contaminated drinking water or direct contact with infected animals (Matsuoka et al., 2004; Mullner et al., 2009). So far, more than 2610 serovars of Salmonella enterica have been recognized from all over the world, and almost all are able to cause illness in humans and animals (Guibourdenche et al., 2010). One of the most important Salmonella serovars is ser. Enteritidis, which is 
an important cause of human illness with symptoms typically including fever, vomiting, diarrhea and abdominal cramps $12-72 \mathrm{~h}$ after ingestion of the bacterium (CDC, 2010). The risk groups of infection with ser. Enteritidis are infants (under 3 months of age), the elderly, and the immunocompromised (CDC, 1990).

Eggs, egg-containing food products and inadequately cooked poultry have been the most common foods source for ser. Enteritidis (Abdullah et al., 2010; Bichler et al., 1994). In the United States, the outbreaks of ser. Enteritidis from 1985 to 1999 were identified as egg-associated (Patrick et al., 2004). There are two routes which can cause contamination of eggs by Salmonella; the first route is horizontal transmission where the infected feces penetrates eggshell pores, or contaminates eggs via cracks on eggs shells (CDC, 2010). The second route is vertical transmission inside the infected hen, where the eggshell membranes, albumen and yolk are contaminated before oviposition (Messens et al., 2005; Gantois et al., 2009). From May 1 to November 30, 2010, approximately 1939 illnesses were reported in the United States that were likely to be associated with ser. Enteritidis (CDC, 2010). Poultry houses are the likely sources of the contaminated eggs with ser. Enteritidis through cracks in the shell (Gantois et al., 2009). Salmonella can survive and persist in poultry houses for a long time. Salmonella has also the ability to spread between hosts, for example bacteria can passage from infected farm animals to vegetables as a result of field fertilization with raw, contaminated manure and Salmonella can infiltrate, colonize and persist on plants (Davies and Wray, 1995; Winfield and Groisman, 2003).

PFGE has been proven to be important for establishing genetic relatedness of different bacterial strains and is commonly used for investigation of outbreaks associated with a particular pathogen (Akiyama et al., 2011; Foley et al., 2009; Ponce et al., 2008; Khan et al., 2002, 2007). PFGE is the current gold standard subtyping method for foodborne bacterial pathogens used by PulseNet, the national molecular subtyping network for foodborne disease surveillance in the United States (Swaminathan et al., 2001). MLVA is another high discriminatory subtyping method that is based on the detection of short sequence repeats in the microbial genome (Seongbeom et al., 2007). Recently, MLVA has been proposed as an alternative to PFGE for subtyping of ser. Enteritidis and a number of other pathogenic bacteria (Boxrud et al., 2007; Ramisse et al., 2004; Svraka et al., 2006). Plasmid profile analysis has been helpful for the characterization of many Salmonella serovars including ser. Enteritidis (Mezal et al., 2013; Ridley et al., 1998). Many strains of Salmonella spp. carry plasmids that play an important role in invasion and survival.

In this study, ser. Enteritidis isolates cultured from poultry houses and clinical specimens isolated during 2010 were examined for PFGE profiles, MLVA typing, plasmid analysis, antibiotic susceptibility and PCR for virulence genes to assess the relatedness among clinical and poultry isolates.

\section{Materials and methods}

\subsection{Bacterial strains}

Sixty isolates of ser. Enteritidis were selected for this study. These strains were isolated from poultry houses during 2010, and clinical samples from Arkansas Department of Health. Twentyeight of these isolates were from poultry houses from the FDA -Arkansas Regional Laboratory (ARL) and thirty-two isolates were of clinical origin and were obtained from the Arkansas Department of Health (ADH). All isolates were stored in Luria-Bertani (LB) broth containing $20 \%$ glycerol at $-70{ }^{\circ} \mathrm{C}$. Organisms were grown overnight at $37{ }^{\circ} \mathrm{C}$ in LB broth or on tryptic soy agar plates supplemented with $5 \%$ blood agar.

\subsection{Antimicrobial susceptibility testing by disk diffusion}

All isolates of ser. Enteritidis used in this study were tested for resistance to eight antimicrobials on Mueller-Hinton agar (Difco Laboratories, Detroit, MI) by a disk agar diffusion method (Khan et al., 2006). The following antimicrobials were used: ampicillin $(10 \mu \mathrm{g})$, chloramphenicol $(30 \mu \mathrm{g})$, gentamicin $(10 \mu \mathrm{g})$, kanamycin $(30 \mu \mathrm{g})$, streptomycin $(10 \mu \mathrm{g})$, sulfisoxazole $(0.25 \mu \mathrm{g})$, tetracycline (30 $\mu \mathrm{g})$, and nalidixic acid (30 $\mu \mathrm{g})$. Sensitivity and resistance were determined by the criteria of the Clinical and Laboratory Standard Institute (CLSI, 2006). Escherichia coli ATCC 25922, which is susceptible to all of the antibiotics, was used for quality control.

\subsection{Pulsed-field gel electrophoresis (PFGE)}

Ser. Enteritidis cells were grown overnight on blood agar plates (Thermo Fisher Scientific, Remel products, Lenexa, KS) at $37{ }^{\circ} \mathrm{C}$. PFGE was performed following a procedure described by Ribot et al. (2006) with some modifications. Each culture was suspended in TE buffer (100 mM Tris- $\mathrm{HCl}, 100 \mathrm{mM}$ EDTA, pH 8.0) to a turbidity of 2.0 and $2.2 \mathrm{OD}_{610}$ as measured using an Ultraspec 3100 pro Spectrophotometer (Pharmacia Biochem Ltd. Cambridge, UK). To prepare the agarose plugs, $20 \mu \mathrm{l}$ of Proteinase $\mathrm{K}(20 \mathrm{mg} / \mathrm{ml}$ stock $)$ was added to $380 \mu \mathrm{l}$ of the adjusted cell suspension. Then $400 \mu \mathrm{l}$ of melted 1\% SeaKem Gold agarose: 1\% SDS was added to the $400 \mu \mathrm{l}$ cell suspension/Proteinase $\mathrm{K}$ mixture and mixed gently. The mixture was immediately dispensed into wells of plug molds. The bacterial cells in the agarose plugs were lysed by treatment with a lysis solution containing $0.1 \mathrm{mg} / \mathrm{ml}$ Proteinase K (GIBCO-BRL, Gaithersburg, MD), $50 \mathrm{mM}$ Tris- $\mathrm{HCl}$ (pH 8.0), $50 \mathrm{mM}$ EDTA, and 1\% $\mathrm{N}$ lauroylsarcosine, for $2 \mathrm{~h}$ at $54^{\circ}{ }^{\circ} \mathrm{C}$.

The plugs were washed two times by adding $10-15 \mathrm{ml}$ sterile water that has been pre-heated to $54-55^{\circ} \mathrm{C}$ and tubes were shaked in a $54^{\circ} \mathrm{C}$ water bath for $15 \mathrm{~min}$. The plugs were washed three times for 15 min with pre-heated sterile TE Buffer (10 mM Tris: $1 \mathrm{mM}$ EDTA, pH 8.0) in a $54{ }^{\circ} \mathrm{C}$ water bath. The plugs were digested with $12 \mathrm{U}$ of restriction enzyme XbaI (Promega Corp., Madison, WI) for $5 \mathrm{~h}$ at $37^{\circ} \mathrm{C}$. Digested fragments were resolved in a $1 \%$ SeaKem Gold agarose (Cambrex Bio Science Rockland, Inc., Rockland, Maine) gel in $0.5 \times$ Tris-Borate-EDTA (TBE) buffer using a contour-clamped homogeneous electric field (CHEF) apparatus (CHEF-DR III, BioRad Laboratories, Richmond, CA). Electrophoresis was performed at $6 \mathrm{~V} / \mathrm{cm}$ with $2.2-54.2 \mathrm{~s}$ linear ramp time for $19 \mathrm{~h}$. Gels were cooled at $14{ }^{\circ} \mathrm{C}$ throughout the run and then stained with ethidium bromide and destained with distilled water. Banding patterns were visualized by UV and photographed. The Salmonella Braenderup strain H9812 PulseNet standard was used as a molecular weight marker after digestion with Xbal. Fingerprinting profiles were examined by using the BioNumerics software version 6.x (Applied Maths, Austin TX) and confirmed visually. Clustering was done by the unweighted pair group average method (UPGMA) using the Dice coefficient.

\subsection{PCR detection of virulence genes}

All isolates of ser. Enteritidis were screened for 17 virulence genes (spvB, spiA, pagC, $m s g A, \operatorname{inv} A, \operatorname{sip} B, \operatorname{prg} H, \operatorname{spaN}, \operatorname{org} A, \operatorname{tol} C$, iroN, sitC, IpfC, sifA, sopB, cdtB and pefA) by a simplex PCR method (Skyberg et al., 2006). Primers used for this study are listed in Table 1. Total genomic DNA from the isolates was extracted from overnight cultures by using the DNeasy ${ }^{\circledR}$ Blood and Tissue kit (Qiagen, Valencia, CA, USA). The composition of the PCR mixture was: $1 \times$ PCR buffer, $200 \mu \mathrm{M}$ of each dNTP, $0.25 \mu \mathrm{M}$ of forward and reverse primers, 2.5 units of Taq DNA polymerase (Qiagen) and $1 \mu \mathrm{l}$ of template DNA. The PCR cycling conditions were 5 min at $95^{\circ} \mathrm{C}$; 
Table 1

Primers used in PCR for detection of virulence genes in S. Enteritidis.

\begin{tabular}{|c|c|c|c|}
\hline Gene & Sequence of nucleotides & Size (bp) & Function of gene \\
\hline \multirow[t]{2}{*}{$s p v B$} & F-CTATCAGCCCCGCACGGAGAGCAGTTTTTA & 717 & Growth within host \\
\hline & R-GGAGGAGGCGGTGGCGGTGGCATCATA & & \\
\hline \multirow[t]{2}{*}{ spiA } & F-CCAGGGGTCGTTAGTGTATTGCGTGAGATG & 550 & Survival within macrophage \\
\hline & R-CGCGTAACAAAGAACCCGTAGTGATGGATT & & \\
\hline \multirow[t]{2}{*}{ pagC } & F-CGCCTTTTCCGTGGGGTATGC & 454 & Survival within macrophage \\
\hline & R-GAAGCCGTTTATTTTTGTAGAGGAGATGTT & & \\
\hline \multirow[t]{2}{*}{$c d t B$} & F-ACAACTGTCGCATCTCGCCCCGTCATT & 268 & Host recognition/invasion \\
\hline & R-CAATTTGCGTGGGTTCTGTAGGTGCGAGT & & \\
\hline \multirow[t]{2}{*}{$m s g A$} & F-GCCAGGCGCACGCGAAATCATCC & 189 & Survival within macrophage \\
\hline & R-GCGACCAGCCACATATCAGCCTCTTCAAAC & & \\
\hline \multirow[t]{2}{*}{ invA } & F-CTGGCGGTGGGTTTTGTTGTCTTCTCTATT & 1070 & Host recognition/invasion \\
\hline & R-AGTTTCTCCCCCTCTTCATGCGTTACCC & & \\
\hline \multirow[t]{2}{*}{$\operatorname{sip} B$} & F-GGACGCCGCCCGGGAAAAACTCTC & 875 & Entry into nonphagocytic cells \\
\hline & R-ACACTCCCGTCGCCGCCTTCACAA & & \\
\hline \multirow[t]{2}{*}{$\operatorname{prgH}$} & F-GCCCGAGCAGCCTGAGAAGTTAGAAA & 756 & Host recognition/invasion \\
\hline & R-TGAAATGAGCGCCCCTTGAGCCAGTC & & \\
\hline \multirow[t]{2}{*}{ span } & F-AAAAGCCGTGGAATCCGTTAGTGAAGT & 504 & Entry into nonphagocytic cells \\
\hline & R-CAGCGCTGGGGATTACCGTTTTG & & \\
\hline \multirow[t]{2}{*}{$\operatorname{org} A$} & F-TTTTTGGCAATGCATCAGGGAACA & 255 & Host recognition/invasion \\
\hline & R-GGCGAAAGCGGGGACGGTATT & & \\
\hline \multirow[t]{2}{*}{ tolC } & F-TACCCAGGCGCAAAAAGAGGCTATC & 161 & Host recognition/invasion \\
\hline & R-CCGCGTTATCCAGGTTGTTGC & & \\
\hline \multirow[t]{2}{*}{ iron } & F-ACTGGCACGGCTCGCTGTCGCTCTAT & 1205 & Iron acquisition \\
\hline & R-CGCTTTACCGCCGTTCTGCCACTGC & & \\
\hline \multirow[t]{2}{*}{ sitC } & F-CAGTATATGCTCAACGCGATGTGGGTCTCC & 768 & Iron acquisition \\
\hline & R-CGGGGCGAAAATAAAGGCTGTGATGAAC & & \\
\hline \multirow[t]{2}{*}{ IpfC } & F-GCCCCGCCTGAAGCCTGTGTTGC & 641 & Host recognition/invasion \\
\hline & R-AGGTCGCCGCTGTTTGAGGTTGGATA & & \\
\hline \multirow[t]{2}{*}{ sifA } & F-TTTGCCGAACGCGCCCCCACACG & 449 & Filamentous structure formation \\
\hline & R-GTTGCCTTTTCTTGCGCTTTCCACCCATCT & & \\
\hline \multirow[t]{2}{*}{ sopB } & F-CGGACCGGCCAGCAACAAAACAAGAAGAAG & 220 & Host recognition/invasion \\
\hline & R-TAGTGATGCCCGTTATGCGTGAGTGTATT & & \\
\hline \multirow[t]{2}{*}{ pefA } & F-GCGCCGCTCAGCCGAACCAG & 157 & Host recognition/invasion \\
\hline & R-GCAGCAGAAGCCCAGGAAACAGTG & & \\
\hline
\end{tabular}

30 cycles of $40 \mathrm{~s}$ at $94^{\circ} \mathrm{C}, 60 \mathrm{~s}$ at $66.5^{\circ} \mathrm{C}$, and $90 \mathrm{~s}$ at $72{ }^{\circ} \mathrm{C}$, with an additional extension for $10 \mathrm{~min}$ at $72{ }^{\circ} \mathrm{C}$. The PCR products were visualized by electrophoresis on $1.2 \%$ agarose gels in $1 \times$ TAE buffer at $50 \mathrm{~V}$ for $85 \mathrm{~min}$.

\subsection{Multiple-Locus Variable-Number Tandem Repeat Analysis (MLVA)}

Multiple-Locus Variable-Number Tandem Repeat Analysis (MLVA) was performed according to the procedures described in the Laboratory Standard Operating Procedure for PulseNet MLVA of S. enterica serotype Enteritidis - Beckman Coulter CEQ and PulseNet Standard Operating Procedure for Analysis of MLVA data of $S$. enterica serotype Enteritidis in BioNumerics - Beckman Coulter CEQ 8000 data (http://www.pulsenetinternational.org/protocols/ Pages/mlva.aspx). The composite analysis was based on equal weighting of XbaI and MLVA data and unweighted pair group method with arithmetic mean (UPGMA) clustering.

\section{6. $P C R$ detection of plasmid replicon typing}

All 60 Salmonella isolates were screened for 15 plasmid replicons by a simplex PCR method (Carattoli et al., 2005). Primers are listed in Table 2. The final volume of PCR reaction mixture was $20 \mu \mathrm{l}$ that included $1 \mu \mathrm{l}$ of template DNA, $1 \times$ PCR buffer, $200 \mu \mathrm{M}$ of each dNTP, $0.25 \mu \mathrm{M}$ of forward and reverse primers, and 2.5 units of Taq DNA polymerase. The PCR amplification conditions were included $5 \mathrm{~min}$ at $94{ }^{\circ} \mathrm{C}, 30 \mathrm{~s}$ at $94{ }^{\circ} \mathrm{C} ; 30$ cycles of $30 \mathrm{~s}$ at $60^{\circ} \mathrm{C}$, and $90 \mathrm{~s}$ at $72{ }^{\circ} \mathrm{C}$, and a final extension for $5 \mathrm{~min}$ at $72{ }^{\circ} \mathrm{C}$. Products of PCR were electrophoresed on $1.2 \%$ agarose gel containing ethidium bromide
Table 2

Primers used in PCR for detection of plasmid replicon typing in S. Enteritidis.

\begin{tabular}{|c|c|c|c|}
\hline Replicon & Sequence of nucleotides & Size (bp) & Target site \\
\hline \multirow[t]{2}{*}{ HI1 } & F-GGAGCGATGGATTACTTCAGTAC & 471 & parA-parB \\
\hline & R-TGCCGTTTCACCTCGTGAGTA & & \\
\hline \multirow[t]{2}{*}{ HI2 } & F-TTTCTCCTGAGTCACCTGTTAACAC & 644 & iterons \\
\hline & R-GGCTCACTACCGTTGTCATCCT & & \\
\hline \multirow[t]{2}{*}{ I1 } & F-CGAAAGCCGGACGGCAGAA & 139 & RNAI \\
\hline & R-TCGTCGTTCCGCCAAGTTCGT & & \\
\hline \multirow[t]{2}{*}{$X$} & F-AACCTTAGAGGCTATTTAAGTTGCTGAT & 376 & ori $\gamma$ \\
\hline & R-TGAGAGTCAATTTTTATCTCATGTTTTAGC & & \\
\hline \multirow[t]{2}{*}{$L / M$} & F-GGATGAAAACTATCAGCATCTGAAG & 785 & $\operatorname{rep} A, B, C$ \\
\hline & R-CTGCAGGGGCGATTCTTTAGG & & \\
\hline \multirow[t]{2}{*}{$N$} & F-GTCTAACGAGCTTACCGAAG & 559 & rep $A$ \\
\hline & R-GTTTCAACTCTGCCAAGTTC & & \\
\hline \multirow[t]{2}{*}{ FIA } & F-CCATGCTGGTTCTAGAGAAGGTG & 462 & iterons \\
\hline & R-GTATATCCTTACTGGCTTCCGCAG & & \\
\hline \multirow[t]{2}{*}{ FIIB } & F-GGAGTTCTGACACACGATTTTCTG & 702 & rep $A$ \\
\hline & R-CTCCCGTCGCTTCAGGGCATT & & \\
\hline \multirow[t]{2}{*}{$W$} & F-CCTAAGAACAACAAAGCCCCCG & 242 & $\operatorname{rep} A$ \\
\hline & R-GGTGCGCGGCATAGAACCGT & & \\
\hline \multirow[t]{2}{*}{ FIC } & F-GTGAACTGGCAGATGAGGAAGG & 262 & rep $A 2$ \\
\hline & R-TTCTCCTCGTCGCCAAACTAGAT & & \\
\hline \multirow[t]{2}{*}{$A / C$} & F-GAGAACCAAAGACAAAGACCTGGA & 465 & rep $A$ \\
\hline & R-ACGACAAACCTGAATTGCCTCCTT & & \\
\hline \multirow[t]{2}{*}{$T$} & F-TTGGCCTGTTTGTGCCTAAACCAT & 750 & rep $A$ \\
\hline & R-CGTTGATTACACTTAGCTTTGGAC & & \\
\hline \multirow[t]{2}{*}{ FIIA (FIIS) } & F-CTGTCGTAAGCTGATGGC & 270 & rep $A$ \\
\hline & R-CTCTGCCACAAACTTCAGC & & \\
\hline \multirow[t]{2}{*}{$K / B$} & F-GCGGTCCGGAAAGCCAGAAAAC & 160 & RNAI \\
\hline & R-TCTTTCACGAGCCCGCCAAA & & \\
\hline \multirow[t]{2}{*}{$B / O$} & F-GCGGTCCGGAAAGCCAGAAAAC & 159 & RNAI \\
\hline & R-TCTGCGTTCCGCCAAGTTCGA & & \\
\hline
\end{tabular}


in $1 \times$ TAE buffer at $50 \mathrm{~V}$ for $85 \mathrm{~min}$, and visualized by using BIORAD Gel DOC XR imaging system.

\subsection{Plasmid profiling}

Plasmid DNA of the strains was isolated by using the alkaline lysis method following the protocol of Ponce et al. (2008). $1.5 \mathrm{ml}$ from overnight cultures of bacterial growth in Luria broth (LB, Difco) was centrifuged at $12,000 \times g$ for $1 \mathrm{~min}$. The pellet was resuspended in $1 \mathrm{ml}$ of SET buffer (20\% sucrose, $50 \mathrm{mM}$ EDTA, and $50 \mathrm{mM}$ Tris $-\mathrm{HCl}, \mathrm{pH} 7.6$ ), centrifuged for $1 \mathrm{~min}$ at $12,000 \times \mathrm{g}$ and resuspended in $150 \mu \mathrm{l}$ of SET buffer. Cells were lysed by mixing with $350 \mu$ lysis buffer ( $1 \%$ SDS and $0.2 \mathrm{M} \mathrm{NaOH}$ ) and incubated for $30 \mathrm{~min}$ in ice. Then, $250 \mu \mathrm{l}$ of acetate buffer (3.0 M sodium acetate, $\mathrm{pH} 4.8$ ) was added. Tubes were mixed by inversion and incubated for $20 \mathrm{~min}$ in ice. After centrifugation at $12,000 \times \mathrm{g}$ at $4{ }^{\circ} \mathrm{C}, 700 \mu \mathrm{l}$ of the upper aqueous phase was transferred to a clean tube and DNA was precipitated by one volume of isopropyl alcohol. The pellets were washed with $1 \mathrm{ml}$ ethanol and dissolved in $50 \mu \mathrm{l}$ of TE buffer ( $50 \mathrm{mM}$ Tris, $1 \mathrm{mM}$ EDTA, pH 8.0). The plasmids were separated on $1.0 \%$ agarose gels in $1 \times$ Tris-acetateEDTA (TAE) buffer at $64 \mathrm{~V}$ for $2 \mathrm{~h}$. The supercoiled DNA ladder (Invitrogen Corporation, Carlsbad, CA) was used as a molecular marker. The molecular sizes of plasmids were determined by

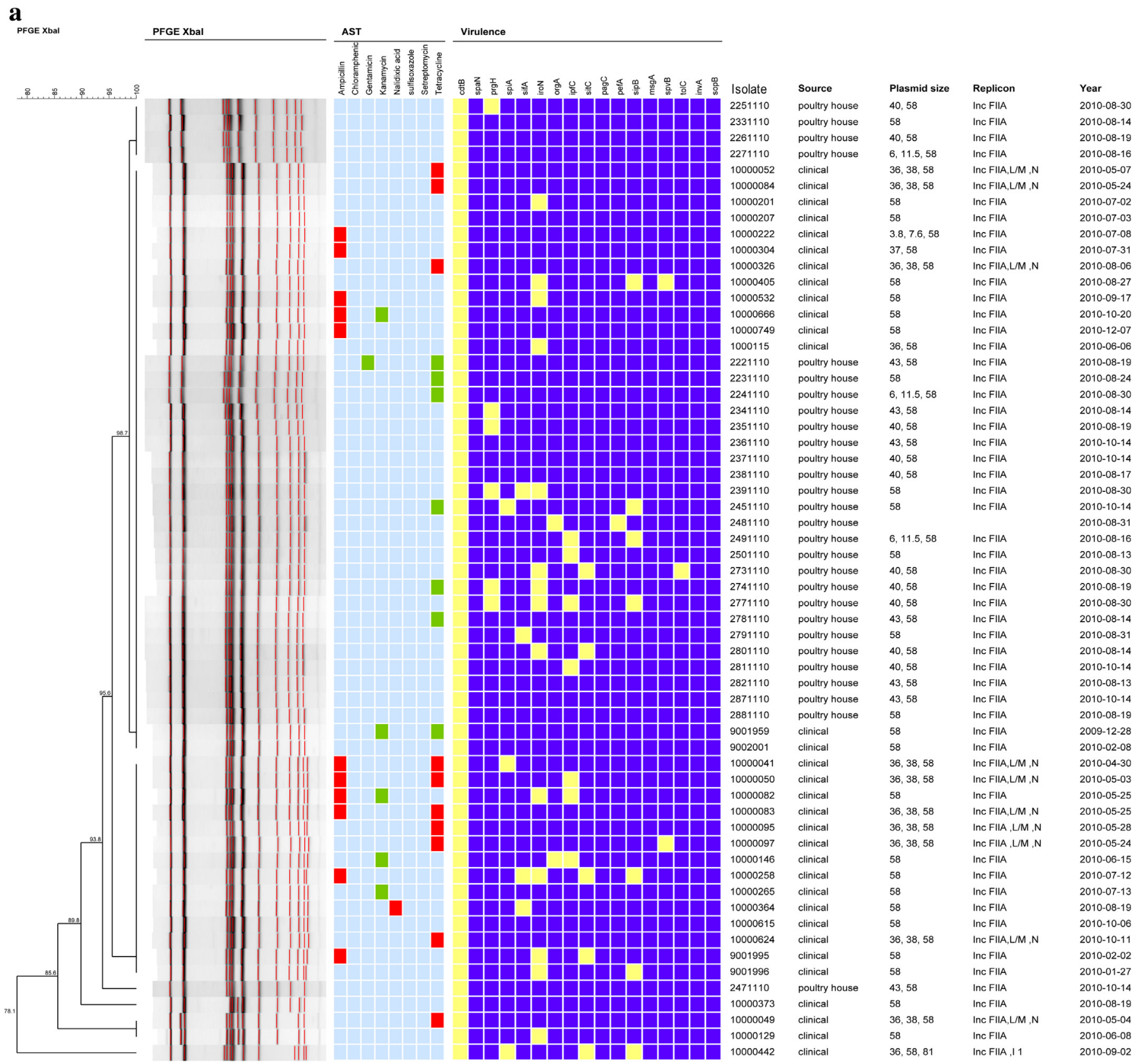

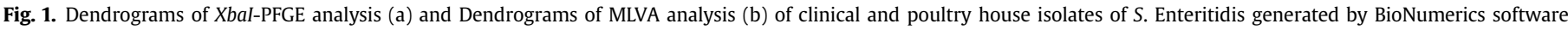

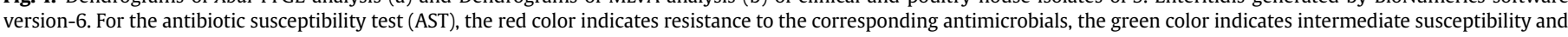

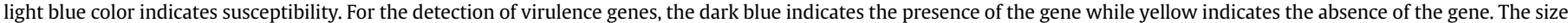

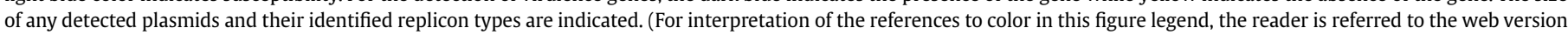
of this article.) 


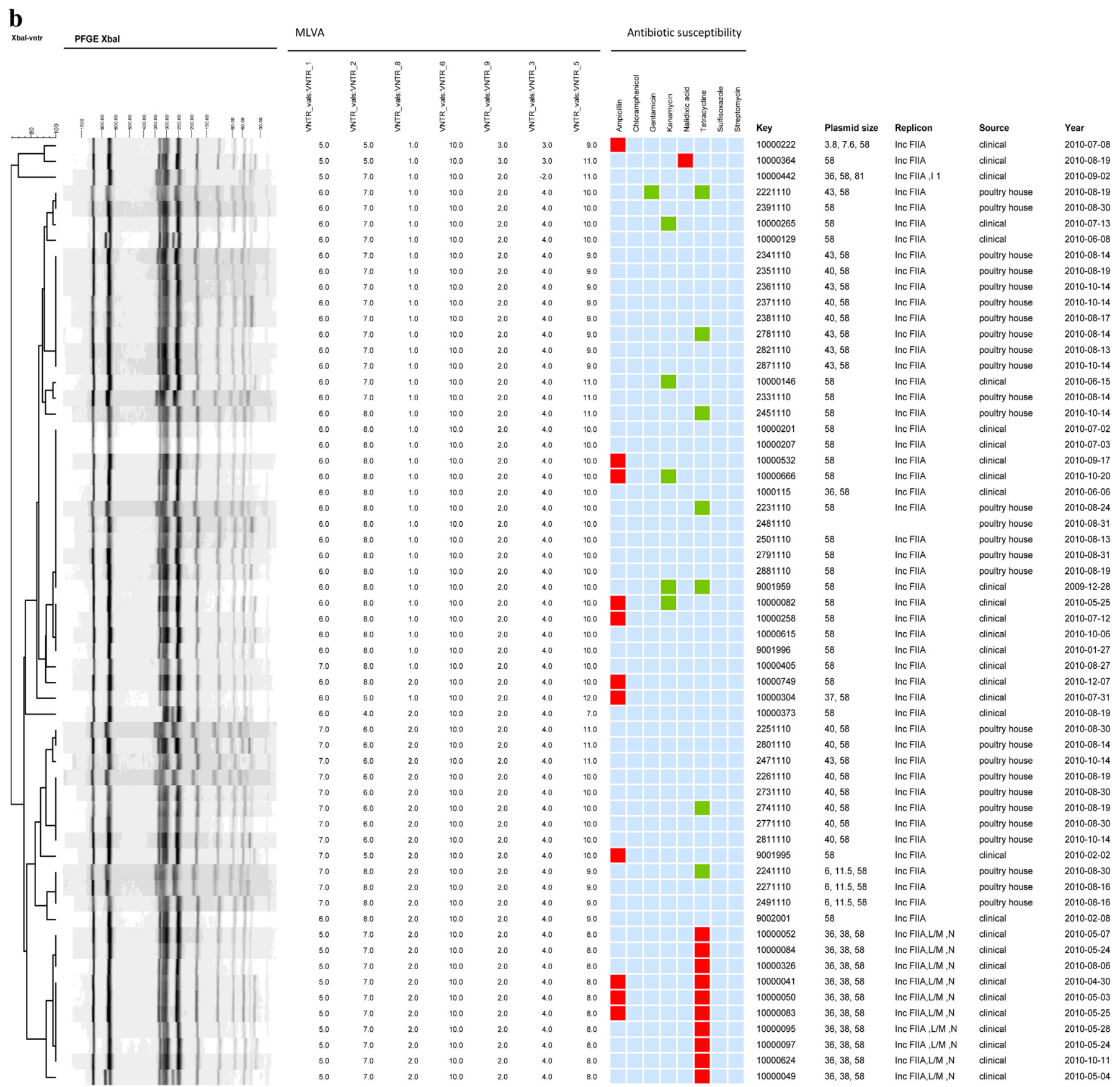

Fig. 1. (continued)

using S1 nuclease (Promega, Madison, WI), following a procedure described by Akiyama et al. (2011).

\subsection{Southern hybridization of plasmid DNA}

A 270-bp PCR product was amplified using IncFIIA primers (Carattoli et al., 2005) from a Salmonella plasmid with the IncFIIA gene, which was PCR labeled by PCR (DIG) Probe Synthesis Kit (Roche Diagnostics, Mannheim, Germany). The plasmids were separated on $0.8 \%$ agarose gels and stained with ethidium bromide for visualization, then transferred and cross linked to positively charged nylon membranes (Roche, Indianapolis, IN). The resulting blot was incubated at $65{ }^{\circ} \mathrm{C}$ for $30 \mathrm{~min}$ in DIG Easy Hyb (Roche) prior to addition of digoxigenin (DIG)-labeled DNA probe (denatured at $95{ }^{\circ} \mathrm{C}$ for $10 \mathrm{~min}$ ). The nylon membranes were hybridized with an IncFIIA gene probe at $45{ }^{\circ} \mathrm{C}$ overnight in a DIG Hyb Solution (Roche) according to the manufacturer's instructions to detect probe target hybrids. Briefly, the membrane was washed in $2 \times$ SSC $(1 \times$ SSC is comprised of $0.015 \mathrm{M}$ sodium citrate and $0.15 \mathrm{M} \mathrm{NaCl}-0.1 \%$ SDS solution twice for 5 min each time at room temperature. The membrane was then washed twice for $15 \mathrm{~min}$ in $0.1 \times$ SSC $-0.1 \%$ SDS solutions at $68^{\circ} \mathrm{C}$. The membrane was blocked in $1 \%$ blocking reagent (DIG) for $30 \mathrm{~min}$ at room temperature. DIG-labeled probe was detected with alkaline phosphateconjugated anti-DIG antibody (Roche) and the chemiluminescent substrate, disodium 3-(4-methoxyspiro (1, 2-dioxetane-3, 2' (5'-chloro) tricyclo [3.3.1.13.7] decan)-4-yl) phenylphosphate (CSPD, Roche). 


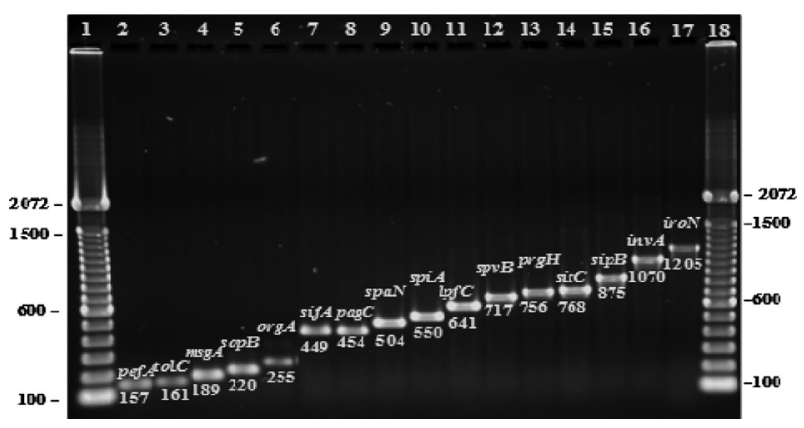

Fig. 2. Agarose gel electrophoresis of amplified DNA in the simplex PCR protocol from $S$. Enteritidis strain 247110 using specific primers (Table 1) for virulence genes. Lane, 1 and 18,100 bp ladder, Lane 2 to 17 PCR products of (from left to right) pefA, tolC, msgA, sopB, $\operatorname{org} A, \operatorname{sif} A, \operatorname{pag} C, \operatorname{spaN}, \operatorname{spi} A, \operatorname{lpfC}, \operatorname{spv} B, \operatorname{prg} H, \operatorname{sit} C, \operatorname{sip} B, \operatorname{inv} A$, iroN virulence genes.

\section{Results}

Antimicrobial susceptibility testing of 60 ser. Enteritidis strains showed that all twenty-eight poultry isolates and ten of the 32 clinical isolates were sensitive to all eight antimicrobials (Fig. 1) Eleven clinical isolates were resistant to the ampicillin, while ten clinical isolates showed resistance to tetracycline. Only one clinical strain was resistant to nalidixic acid. Eleven of the isolates (five poultry isolates and six clinical isolates) showed intermediate to one or two of the antimicrobials tested (Figs. 1a).

All sixty isolates were positive for twelve or more of the virulence genes tested (Figs. 1a, 2 and 3). Only $c d t B$ was not found in any of the isolates. These results suggest that ser. Enteritidis from poultry is virulent, similar to the clinical isolates that may be capable of causing salmonellosis in humans.

The PFGE typing of sixty ser. Enteritidis isolates by $\mathrm{XbaI}$ resulted in $10-12$ bands and grouped into six clusters each with similarity from $95 \%$ to $81 \%$ (Fig. 1a). The PFGE pattern with XbaI restriction enzyme of isolates from poultry and clinical samples showed considerable overlap. Eighteen MLVA allele profiles were detected among the 60 clinical and environmental isolates, with the majority of isolates displaying patterns $\mathrm{A}, \mathrm{B}$, and $\mathrm{C}$ (Table 3). MLVA pattern names were assigned only to groups consisting of 3 or more isolates. Most of the MLVA allele profiles had been seen before in the PulseNet national MLVA database; however, patterns for two of the clinical isolates (10000442 and 9001995) were new. Additionally, 23 isolates with 5 different MLVA patterns were rare in the database (less than 0.6\%). Analysis of the PFGE and MLVA data as a composite dataset improved the discrimination between isolates significantly compared to either dataset alone, dividing the isolates into 25 different genotypes (Fig. 1b). The largest cluster of isolates in the combined dataset consisted of 11 isolates, which was the only genotype to contain both clinical and environmental isolates.

Several large and small plasmids were isolated from ser. Enteritidis. All isolates carried one or more large plasmids of approximately $58 \mathrm{~kb}$ and $38 \mathrm{~kb}$, and one clinical isolate carried a mega plasmid $(81 \mathrm{~kb})$. Three poultry isolates and one clinical isolate carried small plasmids with sizes ranging from 3.8 to $11.7 \mathrm{~kb}$ (Fig. 1a, 3a). The incompatibility (Inc) groups of plasmids were determined by PCR-based replicon typing, which showed that most of the clinical and poultry isolates carried a $58 \mathrm{~kb}$ plasmid, type IncFIIA. The Southern hybridization of plasmids with the IncFIIA probe showed that the $58 \mathrm{~kb}$ plasmid belongs to the IncFIIA type. One of the isolates, 2481110, did not have the $58 \mathrm{~kb}$ plasmid (Fig. 3a, $3 \mathrm{~b}$ ) indicating that this isolate might have lost this plasmid. On the other hand, IncL/M and IncN types were detected in ten clinical isolates, and most of them were resistant to two antibiotics (Fig. 1a). The PCR methods used in this study for replicon typing did not identify the incompatibility group of all plasmids (Carattoli et al., 2005). These data suggest that MLVA pattern and plasmid profile analysis can be useful in discriminating the isolates from different sources.

\section{Discussion}

Ser. Enteritidis is one of the most common serovars of Salmonella that cause foodborne outbreaks in the U.S. Furthermore, Salmonella serovars have a widespread distribution in the environment and the animal reservoir. Certain unspecified host factors make humans particularly susceptible to infection (CDC, 2006). The environment, e.g., surfaces in and around poultry houses, feed mills and egg water is the likely sources of the infection of layers and contamination of shell eggs, which are a source of ser. Enteritidis infections in humans (Abdullah et al., 2010). Ser. Enteritidis can survive in the environment such as dry materials (dust), feces and animal feed and water for a long time in a dormant state, but can multiply rapidly if a suitable environment is present (Akhtar et al., 2010). Our study shows that ser. Enteritidis isolated from poultry houses carried the same sixteen virulence genes present in clinical isolates, which might play an important role in invasion and survival in the host (Skyberg et al., 2006). These findings confirm that the poultry house isolates are capable of contributing to human infection. Recently, Akiyama et al. (2011) and Mezal et al. (2013) indicated that the isolates from the environment carried the same virulence genes as clinical isolates, which are capable of causing human infections.

Of the 60 ser. Enteritidis isolates examined in this study from poultry and clinical sources, twenty one were resistant to either ampicillin or tetracycline and one was resistant to nalidixic acid.
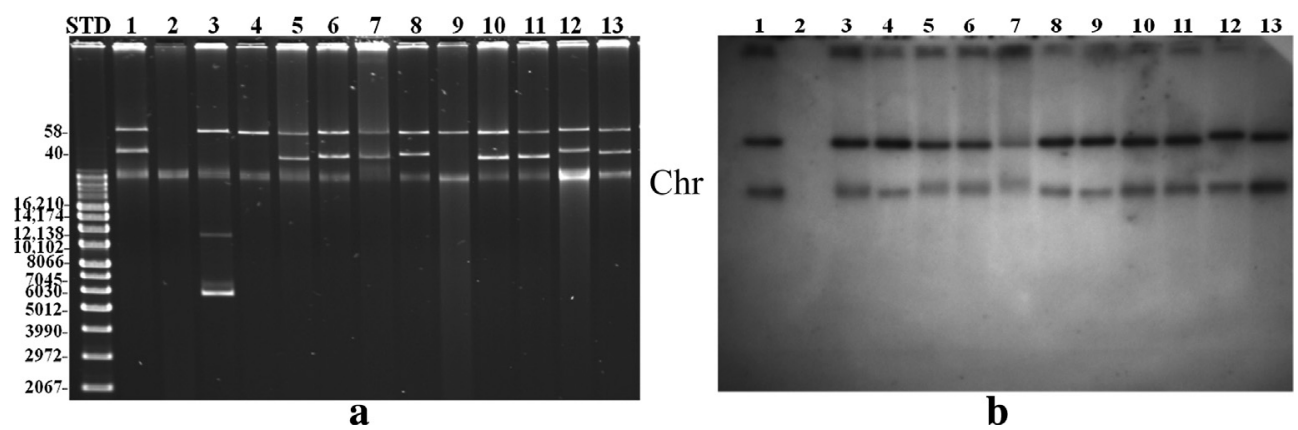

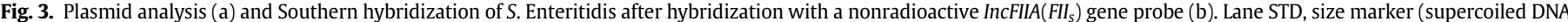

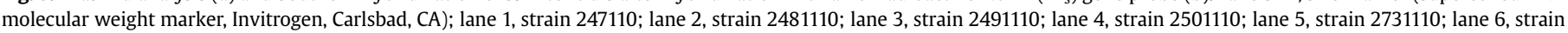
2741110; lane 7, strain 2771110; lane 8, strain 2781110; lane 9, strain 2791110; lane 10, strain 2801110; lane 11, strain 2811110; lane 12, strain 2821110; lane 13, strain 2871110. 
Table 3

Prevalence of MLVA profiles in the PulseNet national MLVA database.

\begin{tabular}{llll}
\hline MLVA type & Allele profile & No. of isolates & $\begin{array}{l}\text { Prevalence in } \\
\text { PN database (\%) }\end{array}$ \\
\hline A & $6-8-1-10-2-4-10$ & 15 & 31.1 \\
B & $5-7-2-10-2-4-8$ & 10 & 0.000042 \\
C & $6-7-1-10-2-4-9$ & 8 & 4.69 \\
D & $7-6-2-10-2-4-10$ & 6 & 0.13 \\
E & $6-7-1-10-2-4-10$ & 4 & 3.87 \\
F & $7-6-2-10-2-4-11$ & 3 & 0.17 \\
G & $7-8-2-10-2-4-9$ & 3 & 0.25 \\
H & $6-7-1-10-2-4-11$ & 2 & 0.78 \\
I & $7-8-1-10-2-4-10$ & 1 & 0.84 \\
J & $6-8-1-10-2-4-11$ & 1 & 4.61 \\
K & $6-8-2-10-2-4-10$ & 1 & 0.40 \\
L & $6-4-2-10-2-4-7$ & 1 & 0.65 \\
M & $6-8-2-10-2-4-9$ & 1 & 0.42 \\
N & $7-5-2-10-2-4-10$ & 1 & New \\
O & $5-7-1-10-2-(-2)-11$ & 1 & New \\
P & $5-5-1-10-3-3-9$ & 1 & 0.95 \\
Q & $5-5-1-10-3-3-11$ & 1 & 1.66 \\
R & $6-5-1-10-2-4-12$ & 1 & 1.26 \\
\hline
\end{tabular}

These resistant isolates were all of clinical origin whereas all poultry isolates were pan-susceptible to antimicrobials, although most of the isolates harbored one or more plasmids. Lower rates of resistance in this study are in agreement with other studies that have reported a low prevalence of antimicrobial resistance among ser. Enteritidis isolates from different sources. Yang et al. (2002) examined 14 and 22 strains each of $S$. Enteritidis and $S$. Typhimurium from sources in South Korea and found that $S$. Typhimurium isolates were extremely high (100\%) compared to S. Enteritidis isolates (21\%).

PFGE is the current gold standard method used to assess relatedness among Salmonella isolates from different sources (Lynne et al., 2009; Ponce et al., 2008) and for outbreak investigations (CDC, 2010). However, PFGE exhibits limited discriminatory power for some serotypes, including ser. Enteritidis (Boxrud et al., 2007).

The PFGE pattern of the ser. Enteritidis isolates from poultry and clinical samples showed considerable overlap, although six main clusters were observed. When PFGE results of poultry isolates were compared to isolates from clinical samples, there was considerable overlap. These results correspond with other observations of limited discriminatory power of PFGE for ser. Enteritidis (CDC, 2010). In this situation, MLVA may add to the discrimination between isolates. This was confirmed in this study where in total 18 different profiles were detected compared to six different XbaI PFGE restriction patterns (Fig. 1b). The 41 isolates that comprised the most common PFGE genotype were distributed among 14 different MLVA patterns. However, even better discrimination was achieved by combining the two methods (Fig. 1b). For example, the 15 isolates that comprised the most common MLVA pattern exhibited two different PFGE types. Additionally, some of the more common PFGE-MLVA composite genotypes were further discriminated by the antimicrobial resistance and plasmid profiles. It can therefore be concluded that for highly clonal organisms, such as serovar Enteritidis, the best resolution is achieved by using a combination of different typing methods.

The high MLVA diversity among the environmental isolates illustrates the complexity of the ecology in a contaminated poultry house. When assessing the interrelationships of the MLVA patterns two key observations can be made: first, many of the patterns are highly divergent from each other, such as patterns $A$ and $F$, indicating that multiple different strains co-exist in the poultry house; this suggests multiple contamination events and sources; second, some of the patterns, such as patterns $\mathrm{D}$ and $\mathrm{F}$, can be considered close variants of each other differing at a single highly variable locus by one to two repeats. This suggests that the strains, once established in the poultry house, evolve over time.

Plasmid profiling has proved to be helpful for differentiation and characterization of Salmonella serovars (Olsen et al., 1994). In our study most isolates carried one or more large plasmids of approximately $58 \mathrm{~kb}$ and $38 \mathrm{~kb}$, with four isolates possessing small plasmids. These results correspond closely to those previously reported (Liebisch and Schwarz, 1996). Additionally, Bichler et al. (1994) have reported the presence of a $54-57 \mathrm{~kb}$ plasmid in ser. Enteritidis.

The Southern hybridization experiments revealed that the $58 \mathrm{~kb}$ plasmid belongs to type IncFIIA in all of the tested ser. Enteritidis isolates. These results correlate with those of the previous study by Rychlik et al. (2006). Ten of the clinical isolates were resistant to ampicillin and tetracycline, which belong to two incompatibility groups (plasmids $L / M$ and $N$ ). Several investigators have shown that Salmonella strains resistant to antimicrobials (blaCTX-M-3 and blaSHV-5 genes) have plasmids of these replicon types (Preston et al., 2003; Carattoli, 2009). These results suggest plasmid profile analysis and typing is a useful and reliable tool for discriminating isolates during outbreaks caused by ser. Enteritidis.

The similarities in virulence genotypes between isolates poultry and clinical indicates that the isolates of poultry are capable of causing human infection through contaminated egg shells, which are the most common source for ser. Enteritidis (Patrick et al., 2004). Most clinical and poultry isolates of ser. Enteritidis belong to one of very few PFGE patterns, and MLVA is a powerful complementary technique to PFGE to further discriminate these isolates. Furthermore, the plasmid profiles are useful and an important epidemiological tool to discriminate ser. Enteritidis strains from various sources. This report and national antimicrobial resistance monitoring system (NARMS) shows that there is a low prevalence of antibiotic resistance among ser. Enteritidis isolates from poultry and clinical sources.

\section{Acknowledgments}

We thank Drs. John B. Sutherland, M. S. Nawaz, and Carl E. Cerniglia for critical review of the manuscript. The authors would like to thank Christine Summage-West for technical help, Gwendolyn Anderson and Stephanie Horton for Salmonella isolates. The authors would like to acknowledge Alessandra Carattoli, Steven Foley, and Rebecca L. Lindsey for replicon typing control strains. The views presented in this article do not necessarily reflect those of the US Food and Drug Administration.

\section{References}

Abdullah, K., Bedir, O, Kocak, N., Levent, B, Eyigun, C. Tekbas, O, Gorenek, L. Baylan, O., Basustaoglu, A., 2010. Analysis of an outbreak of Salmonella Enteritidis by repetitive sequence based PCR and pulsed-field gel electrophoresis. Inter. Med. 49, 31-36.

Akhtar, F., Hussain, I., Khan, A., Rahman, S.U., 2010. Prevalence and antibiogram studies of Salmonella Enteritidis isolated from human and poultry sources. Pakistan Vet. J. 30, 25-28.

Akiyama, T., Khan, A.A., Cheng, C.M., Stefanova, R., 2011. Molecular characterization of Salmonella enterica serovar Saintpaul isolated from imported seafood, pepper, environmental and clinical samples. Food Microbiol. 28, 1124-1128.

Bichler, L.A., Nagaraja, K.V., Pomeroy, B.S., 1994. Plasmid diversity in Salmonella Enteritidis of animal, poultry and human origin. J. Food Prot. 57, 4-11.

Boxrud, D., Pederson, G.K., Wotton, J., 2007. Comparison of multiple-locus variablenumber tandem repeat analysis, pulsed-field gel electrophoresis, and phage typing for subtype analysis of Salmonella enterica serotype Enteritidis. J. Clin. Microbiol. 45, 536-543.

Carattoli, A., Bertini, A., Villa, L., Falbo, V., Hopkins, K.L., Threlfall, E.J., 2005. Identification of plasmids by PCR based replicon typing. J. Microbiol. Methods 63, 219-228.

Carattoli, A., 2009. Resistance plasmid families in Enterobacteriaceae. Antimicrob. Agents Chemother. 53, 2227-2238. 
CDC, 1990. Update: Salmonella Enteritidis infections and grade a shell eggs-United States, 1989. MMWR Morb. Mortal. Wkly. Rep. 38, 877-880.

CDC, 2006. Annual Listing of Foodborne Disease Outbreaks, United States. http:// wwwcdcgov/foodborneoutbreaks/documents/2006_line_list/2006_line_listpdf.

CDC, 2010. Investigation Update: Multistate Outbreak of Human Salmonella Enteritidis Infections Associated with Shell Eggs. http://www.cdc.gov/salmonella/ enteritidis.

Clinical and Laboratory Standards Institute, 2006. Performance Standards for Antimicrobial Susceptibility Testing: Sixteenth Informational Supplement. M100-S16. CLSI, Wayne, PA, USA.

Davies, R.H., Wray, C., 1995. Observations on disinfection regimens used on Salmonella Enteritidis infected poultry units. Poult. Sci. 74, 638-647.

Foley, S.L., Lynne, A.M., Nayak, R., 2009. Molecular typing methodologies for microbial source tracking and epidemiological investigations of gram-negative bacterial food borne pathogens. Inf. Gen. Evol. 9, 430-440.

Gantois, I., Ducatelle, R., Pasmans, F., Haesebrouck, F., Gast, R., Humphrey, T.J., Van Immerseel, F., 2009. Mechanisms of egg contamination by Salmonella Enteritidis. FEMS Microbiol. Rev. 33, 718-738.

Guibourdenche, M., Roggentin, P., Mikoletit, M., Fields, P.I., Bockemuhl, J., Grimont, P.A.D., Weill, F.X., 2010. Supplement 2003-2007(No.47) to the White -Kauffmann-Le Minor scheme. Res. Microbiol. 161, 26-29.

Khan, A.A., McCarthy, S., Wang, R., Cerniglia, C.E., 2002. Characterization of U.S, outbreak strains of Vibrio parahaemolyticus by using Enterobacterial Repetitive Intergenic Consensus [ERIC] PCR and development of rapid PCR method for the detection of 03:K6 strains. FEMS Microbiol. Lett. 206, 209-214.

Khan, A.A., Cheng, C.M., Khanh, T.V., Summage-West, C, Nawaz, M.S., Khan, S.A. 2006. Characterization of class 1 integron resistance gene cassettes in Salmonella enterica serovars Oslo and Bareily from imported seafood. J. Antimicrob. Chemother. 58, 1308-1310.

Khan, A.A., Melvin, C., Dagdag, E.B., 2007. Identification and molecular characterization of Salmonella spp. from unpasteurized orange juices and identification of new serotype Salmonella strain S. enterica serovar Tempe. Food Microbiol. 24, 539-543.

Liebisch, B., Schwarz, S., 1996. Molecular typing of Salmonella enterica subsp. enterica serovar Enteritidis isolates. J. Med. Microbiol. 44, 52-59.

Lynne, A.M., Kaldhone, P., David, D., White, D.G., Foley, S.L., 2009. Characterization of antimicrobial resistance in Salmonella enterica serotype Heidelberg isolated from food animals. Foodborne Pathog. Dis. 6, 207-215.

Matsuoka, D.M., Costa, S.F., Mangini, C., 2004. A nosocomial outbreak of Salmonella Enteritidis associated with lyophilized enteral nutrition. J. Hosp. Infect. 58, 122127.

Messens, W., Grijspeerdt, K., Herman, L., 2005. Eggshell penetration by Salmonella: a review. World Poult. Sci. J. 61, 71-85.

Mezal, E.H., Stefanova, R., Khan, A.A., 2013. Isolation and molecular characterization of Salmonella enterica serovar Javiana from food, environmental and clinical samples. Int. J. Food Microbiol. 164, 113-118.
Mullner, P., Jones, G., Noble, A., Spencer, S.E., Hathaway, S., French, N.P., 2009. Source attribution of food-borne zoonoses in New Zealand: a modified Hald model. Risk Analys. 29, 970-984.

Olsen, J.E., Skov, M.N., Threlfall, E.J., Brown, D.J., 1994. Clonal lines of Salmonella enterica serotype Enteritidis documented by typing. J. Med. Microbiol. 40, 15-22.

Patrick, M.E, Adcock, P.M. Gomez, T.M. Altekruse, S.F, Holland, B.H., Tauxe, R.V. Swerdlow, D.L., 2004. Salmonella Enteritidis infections, United States, 19841999. Emerg. Infect. Dis. 10, 1-7.

Ponce, E., Khan, A.A., Cheng, C.M., Summage-West, C., Cerniglia, C.E., 2008. Prevalence and characterization of Salmonella enterica serovar Weltevreden from imported seafood. Food Microbiol. 25, 29-35.

Preston, K.E., Graffunder, E.M., Evans, A.M., Venezia, R.A., 2003. Survey of plasmidassociated genetic markers in Enterobacteriaceae with reduced susceptibilities to cephalosporins. Antimicrob. Agents Chemother. 47, 2179-2185.

Ramisse, V., Houssu, P., Hernandez, E., Denoeud, F., Hilaire, V., Lisanti, O., Ramisse, F. Cavallo, J.D., Vergnaud, G., 2004. Variable number of tandem repeats in Salmonella enterica subsp. enterica for typing purposes. J. Clin. Microbiol. 42, $5722-5730$

Ribot, E.M., Fair, M.A., Gautom, R., Cameron, D.N., Hunter, S.B., Swaminathan, B. Barrett, T.J., 2006. Standardization of pulsed-field gel electrophoresis protocols for the subtyping of Escherichia coli 0157:H7, Salmonella, and Shigella for PulseNet. Foodborne Pathog. Dis., 59-67.

Ridley, A.M. Threlfall, EJ., Rowe, B., 1998. Genotypic characterization of Salmonella Enteritidis phage types by plasmid analysis, ribotyping and pulsed-field gel electrophoresis. J. Clin. Microbiol. 36, 2314-2341.

Rychlik, I., Gregorova, D., Hradecka, H., 2006. Distribution and function of plasmids in Salmonella enterica. J. Vet. Microbiol. 112, 1-10.

Scallan, E., Hoekstra, R.M., et al., 2011. Foodborne illness acquired in the United States-major pathogens. Emerg. Infect. Dis. 17 (1), 7-15.

Seongbeom, C., Boxrud, D.J., Bartkus, J.M., Whittam, T.S., Saeed, M., 2007. Multiplelocus variable-number tandem repeat analysis of Salmonella Enteritidis isolates from human and non-human sources using a single multiplex PCR. FEMS Microbiol. Lett. 275, 16-23.

Skyberg, J.A., Logue, C.M., Nolan, L.K., 2006. Virulence genotyping of Salmonella spp. with multiplex PCR. Avian Dis. 50, 77-81.

Svraka, S., Toman, R., Skulterty, L., Slaba, K., Homan, W.L., 2006. Establishment of a genotyping scheme for Coxiella burnetii. FEMS, Microbiol. Lett. 254, 268-274.

Swaminathan, B., Barrett, T.J., Hunter, S.B., Tauxe, R.V., et al., 2001. PulseNet: the molecular subtyping network for foodborne bacterial disease surveillance United States. Emerg. Infect. Dis. 7, 382-389.

Winfield, M.D., Groisman, E.A., 2003. Role of no host environments in the lifestyles of Salmonella and Escherichia coli. Appl. Environ. Microbiol. 69, 3687-3694.

Yang, S., Park, K.Y., Kim, S.H., Min No, K., Besser, T.E., Yoo, H.S., Kim, S.H., Lee, B.K. Park, Y.H., 2002. Antimicrobial resistance in Salmonella enterica serovars Enteritidis and Typhimurium isolated from animals in Korea: comparison of phenotypic and genotypic resistance characterization. Vet. Microbiol. 112, 1-10. 